\title{
Assessing the Potential for Global Economic Governance Reform ${ }^{1}$
}

\author{
D.D. Bradlow
}

Daniel D. Bradlow - SARCHI Professor of International Development Law and African Economic Relations, University of Pretoria and Professor of Law Emeritus, American University Washington College of Law; University of Pretoria, Private bag X20, Hatfield 0028, South Africa; E-mail: danny. bradlow@up.ac.za

\begin{abstract}
Every dynamic social system's adaptive capacity is finite. Eventually, the ability of the system's legal and institutional arrangements to adapt to the changing operational context is exhausted. At this point, unless the system is significantly reformed, it begins losing its legitimacy and efficacy.

This article contends that the structure, operation and scale of the global economy has changed so dramatically that the current arrangements for global economic governance are approaching this crisis moment. They are failing to deliver an inclusive, sustainable and efficient international economic system that can contribute to peace, prosperity and human welfare. Their governance arrangements and operating practices and procedures have not been adequately adapted to the new realities of the international political economy. Key institutions are only slowly adjusting their current decision-making practices to the fact that the balance of economic power among their members has shifted. They have also been slow in responding to the growing importance of such non-state actors as corporations, civil society organizations and subnational governments in the governance of the global economy.

The political will to make the necessary changes to the institutional arrangements for global economic governance is lacking. This means that in the short to medium term, absent a serious crisis, there is limited potential for reform. However, this does not mean that opportunities for meaningful partial reforms do not exist. Those actors that are interested in reform need to carefully seek out those opportunities and, once identified, use them to make the system more participatory, accountable and responsive to the concerns to all stakeholders in the system. This in turn should enhance the capacity of the system to respond productively to future opportunities for more profound changes in global economic governance.

In making this case, the article first briefly describes the key features of the order established after World War II. Second, it discusses some of the changes that these institutions have undergone over the past 70 years. Third, it discusses the adjustments that, in fact, have been made in global economic governance. It also indicates some ways in which opportunities for making the system more inclusive, responsive and accountable can be identified. Finally, it offers suggestions regarding possible changes within the current order and on the role entities like the Group of 20 and the BRICS grouping of Brazil, Russia, India, China and South Africa can play in promoting these changes.

It should be noted that, due to space limitations, while this article discusses global economic governance in general, it concentrates primarily on the cases of the two most prominent institutions in global economic governance - the International Monetary Fund (IMF) and the World Bank Group (the World Bank). The reason for focusing on the IMF is that it is the most significant multilateral institution active in the governance of international financial and monetary affairs. The World Bank is an important funder of development activity even if it is not the largest such lender. It is the model that was used in setting up all of the regional multilateral development banks (MDBs) and it has had an influence on the structure and function of other MDBs. It has also been a thought leader in the area of development finance.
\end{abstract}

\footnotetext{
${ }^{1}$ The editorial board received the article in October 2018.
} 
Kew words: global governance; International Monetary Fund (IMF); World Bank

For citation: Bradlow D.D. (2018) Assessing the Potential for Global Economic Governance Reform. International Organisations Research Journal, vol. 13, no 4, pp. 213-236 (in English). DOI: 10.17323/19967845-2018-04-10.

\section{History and Evolution Over the Past 70 Years}

The institutional arrangements for global economic governance that the allies agreed to as World War II was ending were designed to promote peace and human development, and to prevent the destructive military, trade and currency wars that had characterized the previous three decades [Haq et al., 1995; Helleiner, 2014]. The international organizations that they established had a number of specific characteristics that were intended to make them function effectively and sustainably. First, in addition to the United Nations (UN) itself, they established a set of specialized agencies that were linked to the UN. Each of these agencies would be responsible for a particular aspect of global economic governance. Thus, the mandate of the International Monetary Fund (IMF) was to oversee a rules-based international monetary order in which participants agreed to maintain relatively fixed exchange rates ("par values") in return for having access to financial support when they faced balance of payments problems and were unable to maintain the agreed value of their currency [IMF, 1945]. The International Trade Organization (ITO) would develop the rules governing international trade and such issues as employment, trade in commodities and restrictive business practices [UN, 1948a]. The original task of the International Bank for Reconstruction and Development (IBRD or World Bank) was to help arrange the financing for the reconstruction of post-war Europe and the development of its colonies and the poorer independent countries [IBRD, 1945]. The scope of each institution's specialized mission was defined so as to minimize the risk of overlap between the missions of the different specialized agencies. The UN Economic and Social Council (ECOSOC) was expected to coordinate the work of these organizations [UN, 1945, Ch. X, Art. 71-72]. Thus, the ECOSOC would provide a forum in which the economic aspects of global governance could be coordinated with the peace and security and human rights work of the UN.

Second, the system was based on respect for state sovereignty. This meant that the new international organizations would avoid interfering in the domestic affairs of their member states. ${ }^{2}$ In order to mitigate the risk of disrespecting state sovereignty, the organizations would only engage with their member states through designated government officials. For example, each IMF member state was expected to appoint either the finance ministry or the central bank as the IMF's formal contact point with the member state [IMF, 1945, Art. XII, Sect. 2]. Any engagements with other actors in the member state would be coordinated through the formal contact point. In principle,

${ }^{2}$ See UN [1945, Ch. 1, Art. 2] on non-interference in domestic affairs; IBRD [1945, Art. IV, Sect. 10] provides that political activity is prohibited; the IMF [1945, Art. IV, Sect. 1(i)] requires its members to pay due regard to domestic social conditions. 
this allowed each member state to exercise some control over the IMF's activities in the state.

This arrangement contributed to establishing the mechanism of accountability for these international organizations. Since they would only engage directly with state officials, the IMF and World Bank (international financial institutions (IFIs), collectively) could only directly impact the member state and its officials. Consequently, it was sufficient for the IFIs to be directly accountable only to their member states. These states could use their voice and vote in the organization's decision-making processes to hold it accountable. Since the organizations could not engage directly - that is without the consent of the state officials - with the citizens of the member states, they could not directly impact these non-state actors. As a result, there was no need for the IFIs to be directly accountable to the citizens. The citizens of the member state, it was implicitly assumed, could hold their government accountable if they were dissatisfied with the way in which it engaged with the organization.

Third, the arrangements were based on an acknowledgement of the realities of the geopolitical and economic power relations that existed at the end of the war. This meant that since the powerful states would make the biggest contributions to global economic governance and were the largest beneficiaries of the system, they had the largest stake in its governance. Consequently, they were granted a privileged position in the decision-making structures and procedures of global economic governance. This was achieved through such devices as the veto in the UN Security Council [UN, 1945, Ch. V, Art. 27] and weighted voting in both the IMF [1944, Art. XII, Sect. 5] and the IBRD [1944, Art V, Sect. 3].

These global governance arrangements were not implemented as intended. The ITO was never established. The more narrowly focused General Agreement on Tariffs and Trade (GATT) functioned as the forum for establishing the rules for international trade [WTO, n.d.]. In addition, the Cold War meant that not all of the states that were expected to participate in global governance joined the IMF and the IBRD. For example, those states that belonged to the Warsaw Pact created a different set of governance institutions. ${ }^{3}$

Other post-war developments both undermined the original vision and shaped how these institutions functioned. The first was that the number of states participating in the system increased significantly. There were 44 states at the Bretton Woods conference that created the IMF and the World Bank, of which 35 ratified their articles of agreement [Horsefield, 1969]. Today, these institutions have 189 member states that are more diverse in terms of wealth, size, domestic governance arrangements and economic potential than were the founding states [UN, n.d.; IBRD, n.d.a]. The increased diversity of the membership has complicated the governance of the two institutions. One indicator of this is that while the number of their member states has increased more than four times, the size of the boards of directors of the IFIs has only doubled. ${ }^{4}$

\footnotetext{
${ }^{3}$ Since these institutions no longer played a role in global governance after the Warsaw Pact collapsed, they are not discussed in this article.

${ }^{4}$ Originally both institutions had 12 executive directors each. See original articles, [UN, 1944] and [World Bank (IBRD), 2012]. The IMF now has 24 Executive Directors, see IMF [n.d.a] and the World Bank has 25 Executive Directors, see IBRD [n.d.b].
} 
As a result, the average size of the constituencies represented by each of the executive directors at these institutions has grown and the ability of some of them to represent all members of their constituencies has declined commensurably. For example, currently the two executive directors representing sub-Saharan Africa have over 20 countries in their respective constituencies [IMF, n.d.a]. This number is too large to ensure that the concerns and interests of many of these member states are effectively represented in their decision-making structures. This means that their ability to hold the institutions accountable exists more in theory than in practice.

One consequence of these post-war developments was that the IFIs and the UN did not remain the exclusive fora for global economic governance. The most influential states began to resort to alternate international fora for managing the global economy. For example, the United States and Western Europe created what became the Organisation for Economic Co-operation and Development (OECD). ${ }^{5}$ In addition, although the founding states of the IMF originally anticipated that the IMF would make the Bank for International Settlements (BIS) redundant, the leading states and their central banks revived it as a forum in which they could discuss international monetary affairs in a more discrete - and less transparent - forum than the IMF [BIS, n.d.a].

Over time, they also began to create smaller and less formal fora in which select groups of states could meet to exchange views on key issues of economic governance and coordinate their positions on these issues. They could then work together to ensure that these positions were adopted and implemented by the IFIs and the other relevant actors in global economic governance. These informal entities include the Group of 7 (later the Group of 8), and the Group of 10 on monetary affairs [Federal Government of Germany, n.d.; BIS, n.d.b]. These more exclusive fora were in fact the source of many of the key governance decisions during the period before the financial crisis in 2008. The G20, which had been established at the ministerial level after the Asian financial crisis, became more prominent after the 2008 crisis when it was elevated to the summit level [Kirton, 1999]. It proclaimed itself to be "the premier forum for our international economic cooperation" in 2009 [G20, 2009, Para 50].

In addition, the dominant financial powers created new bodies to deal with specific common problems. For example, they created the Financial Stability Forum to coordinate the international standard setting bodies (SSBs) in response to the globalization of finance and the regulatory and stability problems that it generated [FSB, n.d.; Goodhart, 2011]. These bodies provided fora in which the financial regulatory authorities from these countries could meet and develop non-binding international financial regulatory standards that would ensure the effective functioning of the international financial system. In fact, these standards are used by the IMF and World Bank in their financial sector assessment programmes [IMF, n.d.b; IBRD, n.d.c]. As a result, these standards, over time, have become de facto more enforceable against states that are members of the IMF and World Bank but are not participants in the FSF and the SSBs than they are against the states that participated in developing the standards. The reason for this is that those states that think they might need IMF financial or technical

${ }^{5}$ For more on the history of the OECD see OECD [1960] and K. Martens and A. Jakobi [2010]. 
assistance inevitably pay more attention to, and are more likely to implement, the suggestions of the IMF than those with no need for IMF assistance. This situation began to change somewhat when the FSF was formalized as the Financial Stability Board (FSB) and its membership expanded to include those G20 states that were not yet members of the FSF. In addition, the SSBs broadened participation in their decisionmaking so that the regulatory authorities from more countries were able to participate in their deliberations.

It should be noted that other states have attempted to enhance their voices in global economic governance by forming analogous informal groupings. These include the Group of 24 on financial and monetary affairs [G24, n.d.] and the Group of 77 plus China in the UN [G77, n.d.]. Another example is the BRICS, which began holding annual summits in the aftermath of the global financial crisis of 2008 [Lukov, 2012; Stuenkel, 2015].

It is also important to recognize that the relationship between the IFIs and the UN never functioned as intended. The IMF and IBRD, despite being specialized UN agencies, quickly established their functional independence from the UN. ${ }^{6}$ Moreover, the richest and most powerful states effectively limited the UN's role in global economic governance. For this reason, the ECOSOC was never able to effectively perform its task of coordinating the political and economic aspects of global affairs. As a result, the peace and security and the human rights agendas of the UN developed separately from the economic policies and operations of the IFIs. This deprived governments, corporations and the institutions themselves of the opportunity to learn about more integrated approaches to the governance of international financial and economic affairs and transactions that may have developed if the ECOSOC had been able to play its intended role.

One consequence of this was that the IFIs were able to treat the social and environmental impacts of economic activity as falling within the ambit of the domestic affairs of the member states. This meant that they viewed these issues as "political" and thus outside the scope of their responsibilities. It also meant that the Universal Declaration of Human Rights did not affect the operation of IFI policies, despite their links to the UN system and the Declaration's stipulation that "every organ of society...shall strive...by progressive measures, national and international, to secure their universal and effective recognition and observance" [UN, 1948b]. This is noteworthy because today many contend that the Declaration's core provisions have the status of customary international law [Hannum, 1996, p. 317]. In addition, these provisions have become binding on the vast majority of IFI member states through the human rights treaties that they have signed and ratified [Aizawa, Bradlow, Wachenfeld, 2018].

The distinction that the IFIs have sought to maintain between political and economic issues has proven to be unsustainable. Over time, it has become undeniable that many of the projects that the World Bank funds have adverse social and environmental

${ }^{6}$ The agreement between the UN and the IMF was approved by the board of governors of the fund on 17 September 1947 and by the UN General Assembly on 15 November 1947, and came into force on 15 November 1947. See IMF [2017a]. See IBRD [1947] for the agreement between the UN and the IBRD on 16 September 1947. 
impacts. The Bank has responded to the failure of a number of the projects that it has funded and to the growing awareness of the multidimensional nature of development by broadening the scope of its operations and the conditions attached to its financing. Now, in addition to project financing, it offers its members policy-based loans and addresses a complex mix of social and environmental issues, including corruption, good governance, treatment of vulnerable population groups and environmental impacts on social groups and public health in its operations [IBRD, n.d.d].

The IMF has gone through an analogous transition. When the rules-based monetary system collapsed in 1973 and was replaced by a market-based system [De Vries, 1986; IMF, 2006; Bradlow, 2011], the IMF could no longer draw clear boundaries around the issues that fell within its international monetary mandate. In the absence of explicit exchange rate rules, it was not clear what the limits on IMF surveillance of its members' balance of payments situation should be. Without the focus of the IMF's original par value system, all financial and economic - and some non-economic - issues became plausibly relevant to the country's ability to maintain a sustainable balance of payments position. These were arguably legitimate issues for the IMF to raise in its surveillance missions and to address in the conditionalities attached to its financial support. In addition, since they were no longer bound to observe rules regarding exchange rates, ${ }^{7}$ the new system deprived the IMF of its influence in countries that did not need, and never expected to need, its financial support. The IMF, in response to these developments, created a new role for itself, focusing its operations on countries in distress. The complexity of their problems caused the IMF to attach wide-ranging, intrusive and detailed conditionalities to its financial support.

More recently, the institutions involved in global economic governance have come under increasing pressure to incorporate human rights concerns into their policies and operations. This pressure arises not only from the impact of their own operations but from the growing recognition both within the business community and broader civil society of the importance of human rights to business and economic activity more generally. ${ }^{8}$ In addition, they must respond to the growing impact of climate change and its complex implications for the social and environmental sustainability of economic development on their operations. ${ }^{9}$ Their failure to respond effectively to these pressures has adversely affected their legitimacy and their effectiveness. These developments serve to highlight the cost of failing to develop a more integrated approach to the governance of development and the global economy.

Another important change relates to the status of the institutions of global economic governance.

As indicated above, there was an initial concern about the ability of these new and untested international organizations to play their intended global governance role. This concern arose because of the risk that a member state could interfere with their operations. As a result, the member states agreed to grant the organizations broad immunity

${ }^{7}$ It should be noted that the one remaining rule was that member states could not fix the value of their currency in terms of gold. See IMF [1945, Art IV, Sect. 2].

${ }^{8}$ See, for example, Human Rights Watch [2017], Darrow [2006] and Bradlow [1996].

${ }^{9}$ See, for example, IBRD [2016]. 
from the jurisdiction of those states. This would include immunity from suit, taxes and interference with their assets. ${ }^{10}$

Today, the status of international organizations in the international order is well established. In fact, instead of being operationally weak, they are able to exercise considerable influence in the economic affairs and projects of many but not all of their member states. Despite their growing influence and the contemporaneous reduction in the scope of sovereign immunity, there has been no change in the immunity of organizations like the IMF, the World Bank and the UN. The result is that today, international organizations are among the least accountable institutions in the world, despite their advocacy of the importance of accountability to good governance for their member states. They are also able to use their immunity - designed as a shield against state interference - as a sword to ward off efforts to hold them accountable for the adverse consequences of their actions [Bradlow, 2017, pp. 45-67].

The creators of the institutions of global economic governance did not anticipate how the range of actors would grow. Initially, states were the only actors on the international stage. Today, corporations, civil society organizations and even individuals play significant roles in the global economy. As a result, it is not feasible to deal effectively with some aspects of global economic governance without the participation of at least some of these categories of non-state actors. This can be seen, for example, in the cases of human rights and climate change discussed above. It is also particularly relevant because of the dramatic changes in international law and information and communications technology that have taken place over the past 70 years. At the time of the establishment of the IFIs, for example, governments were able to develop financial regulatory standards with the expectation that they could enforce their standards within their own jurisdiction. Today, information and communication technologies facilitate cross-border transactions taking place at a speed that government regulators cannot hope to match. The result is that many non-state actors can avoid individual national regulatory frameworks that they do not like, thereby undermining their efficacy. This, in turn, has increased the need for international coordination in financial and economic regulation and for participation by a broader range of state and non-state actors in this coordination [Goodhart, 2011; Helleiner, 2014]. The governance arrangements of the IFIs, like those of other international organizations, have not effectively adapted to this challenge.

The treaties that established these two institutions were shrewdly drafted. They were sufficiently flexible that, even in the absence of significant amendments or governance reforms, they could respond to the complex ways in which the global economic system has evolved over the past 70 years. Initially, the IFIs were able to make enough adjustments in their governance and operational practices to deal with the changes discussed above with reasonable effectiveness. However, over time, as the challenges became bigger and more complex, the limits of the original governance structures and operational practices of the IFIs have become more obvious.

${ }^{10}$ See IMF [1945, Art. IX], IBRD [1945, Art. VII], UN [1946] and The Convention on the Privileges and Immunities of the United Nations, 33 U.N.T.S. 262, 2 December 1948. XXX 
One example is the IMF's response to its transformation into a specialized development monetary and financial institution. The IMF initially maintained that it was overseeing a global monetary system in which all its member states participated and that, therefore, it should treat all its member states uniformly and without regard to level of development. Today, it acknowledges that its membership is not uniform and that, at least for some purposes, their differences are more significant than their similarities. For example, the IMF has limited leverage and influence over its most powerful member states, even if they are following policies that adversely affect most of its membership. This in turn has resulted in it having to impose harsher adjustment burdens on those member states over which it can exert influence than may have been the case in a more balanced system. This imbalance for example is partially responsible for the controversies surrounding the IMF's operations in Latin America and Africa in the 1980s, in Eastern Europe and Asia in the 1990s and its unsuccessful efforts to encourage adjustment in the richest countries prior to the global financial crisis [Vreeland, 2003].

The World Bank has faced analogous challenges in adapting to the changing context of its operations, particularly in regard to its expansion into programmatic and policy-based lending and in regard to the environmental and social impacts of its operations. This has resulted in its operations becoming more complex and, as a result, more contentious and controversial. It has also resulted in an expansion of its mission so that it has become hard for the Bank to limit itself to funding only projects or programmes that constitute "economic" activities within the meaning of its articles. This in turn has called into question the meaning of the political prohibition in its articles and has intensified concerns about the accountability of the Bank [Darrow, 2006].

The other institutions that play a role in global economic governance also face challenges [O'Brien et al., 2000; Jessop, 1998]. For example, the Bank for International Settlements remains a secretive organization controlled by a select group of central banks. Its governance arrangements have not fully adapted to the changing structure of global finance and the important role that non-state actors play in the system. It has also not effectively adapted to the need for a vision of finance that incorporates a more holistic view of development. The FSB and the SSBs are becoming more inclusive but they too have failed to fully incorporate an holistic view of development into their operating policies and practices. The G20, despite its claim to be the premier forum for economic cooperation, has not functioned as an effective instrument of global economic governance except during the most intense phase of the global financial crisis.

\section{Strategies for Change}

It is clear from the above short history that in reality the current arrangements for global economic governance are not fit for their intended purpose. The IFIs are constrained by their structure and specialized mandate. Despite their best efforts, they are unable to effectively adopt and implement a holistic vision of the global economy. For example, while it has shown considerable creativity in implementing its mandate, the World Bank 
cannot simply ignore the political prohibition in its articles. Similarly, the IMF cannot fully overcome its origins as a specialized international monetary organization, which limits its capacity to deal with non-economic issues and become a true development financing institution. In addition, the IFIs' efforts to expand their missions causes them to encroach to a significant extent into the mandates of other international organizations. This creates legitimacy problems for them and undermines the integrity of the global governance system. Finally, they are incapable of incorporating all the relevant actors into their decision-making procedures. Thus, even though non-state actors such as transnational corporations, international civil society, international organizations and networks of experts and subnational governments all now play critical roles in the functioning of the global economy, the IFIs and the other relevant international organizations have not formally involved them in their decision-making structures.

These developments all suggest that the system of global governance needs a radical overhaul. Unfortunately, there does not seem to be any appetite for making the substantial reforms needed to give these institutions the capacity to deal effectively with the challenges that the system is currently facing. However, the international community cannot afford to delay action until the requisite political will manifests itself. The challenges it faces are too great to allow such a luxury. This means that the international community must work to identify and creatively exploit whatever possibilities for governance reform exist within the current institutional arrangements. Failure to do so risks causing a breakdown in global governance with unpredictable consequences for the international community's ability to deal with the implications for the global economy of such issues as climate change, technological change and the promotion of sustainable and equitable development.

The challenge therefore is to identify meaningful current opportunities for reform. This can be done using the following four criteria. First, the potential reform must promote the incorporation of a more holistic vision of development into the governance and operation of the global economy. In other words, the changes must allow for a fuller consideration of the environmental, social and human rights impacts of the global economy and particular activities within it. Second, the opportunities must result in reforms that will both make meaningful improvements in the management of at least one of the four most important problems with the existing arrangements and will contribute to the generation of new possibilities for future change. These problems include: the lack of an effective coordination mechanism to implement the different aspects of a widely accepted holistic vision to guide the global economy; the lack of effective participation by all relevant stakeholders in the decision-making procedures of global governance; the failure to articulate a sustainable and feasible balance between the autonomy of the institutions of global economic governance and the sovereignty of member states; and the lack of accountability of the key institutions of global governance. Third, the reforms must make the institutions more inclusive. This means that that they should make it easier for all states and non-state actors that are active stakeholders in global economic decision-making processes to participate. Fourth, the reforms should address the fact that the IFIs and the other institutions active in global economic gov- 
ernance are operating without effective accountability. Thus, any meaningful reforms must help these institutions to become more accountable to those stakeholders that are affected by their decisions and actions.

Based on these criteria, there are three basic strategies that can lead to meaningful global economic governance reforms. The first is to change the existing international organizations without amending their founding agreements. The second is to use the existing informal bodies such as the G20 and BRICS to promote reforms in the arrangements of global economic governance. The third is to create new international organizations or fora that can play a role in global governance. In fact, the international community has tried all three strategies.

\section{Reforms to the Institutions}

Over the past 30 years there have been a number of reforms in the governance of the IFIs. Most significantly, both institutions have made small adjustments in their voting arrangements to better reflect the changes in the structure of the global economy. Thus key emerging countries like China, India and Brazil have seen their votes increase at the expense of some European countries, but also at the expense of some poorer developing countries [IMF, 2009a; IMF, 2009b]. It is important to note, however, that these changes have not been sufficient. As a result, the distribution of voting power today in these institutions is still biased in favour of the European countries. The second change is that both institutions have converted their boards into fully elected bodies [IMF, n.d.a; IBRD, n.d.e]. In addition, the World Bank has increased the number of seats on its board of executive directors to give greater voice to sub-Saharan African member states. They nevertheless remain the most under-represented group in the governance of the IMF.

The institutions have also become more transparent. Both institutions now have information disclosure policies that are based on the assumption that information should be disclosed unless specifically excluded from disclosure [IMF, 2018; IBRD, 2015]. In fact, most information now ultimately is disclosed, although it might be with some time lag. The World Bank has also become more participatory in the formulation of at least some of its key operational policies and procedures. This means that it invites comments and engages in consultation with interested stakeholders about the content of these policies. ${ }^{11}$ The IMF has become more open to consultation with civil society but does not engage in the same extensive consultations as the Bank when developing its operating policies.

The institutions have also made efforts to become more accountable. The IMF has created an Independent Evaluation Office that reports directly to the board of directors [IEO, n.d.]. The office conducts studies of specific aspects of completed IMF operations and issues public reports [IEO, 2018]. It also publicizes its annual work programme and solicits comments on it. However, while the reports appear to contribute

${ }^{11}$ See IBRD [2016] for a detailed explanation of the process followed to develop the environmental and social framework, which became operational in early 2018. 
to some learning in the IMF, their lessons do not appear to be effectively integrated into its operating policies and practices [IEO, 2018]. In addition, they do not offer non-state actors who may have been adversely affected by identified deficiencies in the IMF's operations any ability to hold the organization accountable.

The World Bank Group has created the Inspection Panel to investigate cases of non-compliance by IBRD and International Development Association staff with the Bank's operational policies and procedures [IBRD, n.d.f]. The International Finance Corporation and the Multilateral Investment Guarantee Agency established the Compliance Advisor Ombudsman to both review cases of non-compliance with their policies and to help resolve disputes arising from its operations [CAO, n.d.]. Both mechanisms are initiated by complaints brought by communities or groups of individuals that claim they have been harmed or are threatened with harm caused by Bank-funded projects. In both cases, however, the mechanisms can issue reports with findings but they cannot provide a remedy in the event that they find harm, and the relevant board of directors and management are not obliged to act on the reports.

\section{Utilization of Other Fora}

As indicated above, the international community has created new governance arrangements to fill gaps in the arrangements for global economic and financial governance. For example, the international community has, or sub-groups within it have, established new informal bodies that play a role in global economic governance. The most prominent recent example is the elevation of the G20 to the summit level. It is now recognized as a premier forum for global economic governance. Other examples, which also operate at the summit level, are the BRICS and the Asia Pacific Economic Cooperation [APEC, n.d.]. These bodies have been supplemented by groupings of nonstate actors that seek to enhance their voices in global economic governance fora. They include such bodies as the T20 [n.d.], B20 [n.d.], L20 [n.d.], and W20 [n.d.]. It is important to note that the channels of communication between these groups and other stakeholders in global governance can be so attenuated that the decision-making bodies may not know about the concerns of all the state and non-state actors that are being affected by their decisions, nor understand all the impacts of their decisions. This weakness may be further exacerbated because their informal structures and relatively opaque decision-making processes make them susceptible to influence by their more powerful stakeholders.

It is important to note that the IMF and the World Bank participate in the G20. Their participation in these bodies helps universalize their outputs even though many of their member states have had no voice in their formulation.

\section{Creation of New Institutions}

In addition to these informal mechanisms, there has been a proliferation of new international organizations and arrangements. These include the Asian Infrastructure 
Investment Bank and the New Development Bank ("the BRICS bank") [NDB, n.d.], and regional monetary arrangements such as the Chiang Mai Initiative Multilateralization [Sussangkam, 2010], the Contingent Reserve Arrangement [BRICS, 2014], the Latin American Integration Association and the Latin American Reserve Fund [IMF, 2017b]. In addition, a number of states including France, the UK and Germany have been working to create a payments mechanism to allow companies from their countries to avoid U.S. dollar-based payments systems when doing business with Iranian companies [Financial Times, 2018]. Individual countries are also undertaking initiatives that are changing global economic governance. For example, the Chinese government has undertaken a massive Belt and Road Initiative that is designed to assist in the development of other countries and to link them in a "belt and road" to China, thereby recreating a modern version of the old silk road [Hurley, Morris, Portelance, 2018].

It is important to note however, that these alternate entities so far are too small or too new to constitute a significant challenge to the existing arrangements.

\section{Short- and Medium-Term Reform Proposals}

The scope for adequately reforming IFI governance so that these institutions can function effectively and with legitimacy is constrained by the historical inertia generated by the current voting arrangements in these institutions. The countries that had the largest voices in the original governance arrangements still effectively retain this control. As their actual role in the international economic order has declined, their incentive to protect their privileged position has increased with adverse effects on the governance of the IFIs. This can be seen, for example, in the failed attempts to meaningfully reform the process for selecting the heads of the IMF and World Bank or in the limited success in adjusting IMF and World Bank voting shares. However, if these institutions wish to remain effective and legitimate, they need to identify ways in which to adapt their decision-making procedures and operational practices to the challenges generated by the changing balance of geopolitical and economic power.

Another constraint on the potential for reform is the continuing resilience of sovereignty. This limits the ability of the institutions of global governance to engage freely with all the relevant non-state actors in their member states. In addition, this constraint inhibits the institutions' ability to develop ways of accommodating all the state and non-state stakeholders whose participation is required to effectively deal with challenges like climate change, demographic imbalances, wealth inequalities and the complex dynamic between global integration and economic exclusion.

Despite these constraints and limitations, there are meaningful but limited reforms that the institutions can implement within their existing legal and institutional structures. These reforms are meaningful in the sense that they satisfy the four criteria listed above. 
Currently, there are four opportunities for meaningfully reforming the institutions of global economic governance. The first relates to participation, particularly by nonstate actors. This is an area in which some progress has already been made, but more progress is possible. The IMF and World Bank, within their existing articles, can create new avenues for participation. For example, as happens in some environmental negotiations, they can create channels that allow key stakeholders like the private sector, subnational governments and civil society to participate in policy making. These channels could include offering non-state actors opportunities to propose policy initiatives, comment on draft policies and to participate in the selection processes for senior management in these institutions, and to allow a limited number of representatives of civil society organizations to make either oral or written submissions to the boards of directors on key policy issues. The institutions could also commit to respecting the applicable soft law instruments that both state and non-state actors have helped develop and that are relevant to their operations. For example, they could commit to conform their own activities to the responsibilities for business specified in such international standards as the UN Guiding Principles on Business and Human Rights. In fact, many of the IFI member states and their companies have endorsed these standards in the UN and other international fora. This commitment, inter alia, would require the IFIs to do human rights impact assessments of their various operations. As some businesses have learned, complying with these standards can have positive effects on their reputation, the outcomes of their operations, the pricing of their debt and the willingness of young people to work for them [Global Compact Network Germany, 2015].

These institutions should pay heed to the principle of subsidiarity in promoting greater participation. It is not necessary that all state and non-state stakeholders participate directly in all global economic governance decisions. It may be adequate for there to be subsidiary bodies in which subsets of actors participate. These lower bodies could bring state and non-state actors together on a geographic, interest area or expertise basis, and could be permanent or ad hoc. Their decisions or views can then be submitted to higher level and more universal bodies for consideration in their decisionmaking procedures.

The second area deals with accountability. The failure of these institutions to become more accountable is problematic. Over the course of the past 70 years, the power of these institutions, relative at least to their smaller and weaker member states, has grown. However, because of their immunity, their accountability to those affected by their actions has not grown commensurably. The World Bank - and the other multilateral development banks - have responded to this need by creating independent accountability mechanisms. While these remain relatively weak, they mean that the World Bank is substantially more accountable than either the IMF or the UN. The failure of these institutions to become meaningfully accountable to all who are directly affected by their operations and to submit themselves to some form of binding accountability is surprising given their strong advocacy of accountability as a part of good gov- 
ernance. As the examples of the independent accountability mechanisms at the MDBs show, this can be done within the scope of the existing articles of agreement.

In this regard, it is useful to note that the issue of the immunity from jurisdiction of international organizations has increasingly come under challenge. There is little doubt that these organizations need some degree of immunity so that they can operate effectively in implementing their mandates in their member countries. However, this immunity should not give them absolute protection when their own actions cause their operations to have direct and adverse effects on non-state actors. As the European courts have recognized, in these situations they should at least provide these actors with a meaningful remedy that can operate as an alternative to a court [European Commission of Human Rights, 1997, European Court of Human Rights, 1999]. The issue is also currently before the U.S. Supreme Court [United States Court of Appeals, 2017].

A third possible area of reform relates to the need for the institutions and fora of global economic governance to fully assess the potential impacts of their proposed projects, policies, norms and standards. This requires that they do comprehensive impact assessments of proposed activities. The World Bank and the MDBs already do social and environmental impact assessments. However, they do not yet do a full human rights impact assessment, even though this has been called for in a number of non-binding UN documents. The IMF, the FSB and the SSBs do assess the potential economic and financial impacts of their programmes and standards. However, they do not assess their social, environmental or human rights impacts. Given that all of these entities have recognized the importance of dealing with the challenges of inequality and exclusionary economic systems and the impact of climate change on the economy, it is hard to understand how they can be sure that their proposals for implementing their mandates are being fulfilled without these studies. Since ultimately the policies and procedures of these institutions and entities are member driven, they are unlikely to make this change in their practices without some indication that it is wanted by their member states. Consequently, one way in which the G20 and the BRICS can contribute to reforming global economic governance is to call on these institutions to do these impact studies.

A fourth area of reform is to more clearly define the role of these institutions in the G20 itself. Currently, the IMF, the World Bank, the OECD and the UN Development Programme participate in many of the meetings of the G20. They are often called upon to do the technical studies that inform the work of the G20 working groups. On the one hand, it is reasonable for these organizations to provide this support to a group of their member states. On the other hand, these groups have broader memberships than the G20. In this regard it should be noted that one concern about the G20 is that it is a selfselected group of countries and that it has no mandate to make policies for the whole world. Consequently, one contribution that these institutions can make to the G20 is to provide them with information on the concerns of their non-G20 member states about the possible impacts of its proposed decisions or declarations on these countries. For example, these entities could regularly include a section in their reports to the G20 on 
the views of non-G20 member states. This would enhance the legitimacy and, potentially, the efficacy of the G20's statements and actions. It may also help promote better communications between these institutions and their member states. Thus the G20 and the BRICS could call on these entities to provide this information to the G20.

This change would be limited and may not even be observable to most stakeholders in the system of global economic governance. Nevertheless it would be a useful change because it would help facilitate the participation, albeit indirectly, of a greater range of interests and voices in the G20 forum. It would also help strengthen the voice of those G20 members that are developing countries.

\section{Conclusion}

The current arrangements for global economic and financial governance are at a critical juncture. They are not performing effectively and their credibility and legitimacy is being undermined. Unfortunately, despite the need for substantial change, significant reforms to these arrangements is not currently feasible. This means that the only realistic option is to aggressively and creatively exploit whatever limited but meaningful opportunities for reforms that can be identified. This article shows that such opportunities exist, and can relatively easily be exploited by entities like the BRICS and the G20.

\section{References}

Aizawa M., Bradlow D., Wachenfeld M. (2018) International Financial Regulatory Standards and Human Rights: Connecting the Dots. Manchester Journal of International Economic Law, vol. 15, no 1. Available at: https://papers.ssrn.com/sol3/papers.cfm?abstract_id=3171933 (accessed 15 October 2018).

Asia-Pacific Economic Cooperation (APEC) (n.d.) How APEC Operates. Available at: https://www. apec.org/About-Us/How-APEC-Operates (accessed 15 October 2018).

Bank for International Settlements (BIS) (n.d.a) BIS History - Overview. Available at: https://www.bis. org/about/history_newarrow.htm (accessed 15 October 2018).

Bank for International Settlements (BIS) (n.d.b) G10. Available at: https://www.bis.org/list/g10publications/ (accessed 15 October 2018).

Bradlow D. (1996) The World Bank, the IMF and Human Rights: Symposium: Social Justice and Development: Critical Issues Facing the Bretton Woods System. Transnational Law and Contemporary Problems, vol. 6 (accessed 15 October 2018).

Bradlow D. (2011) The Reform of the Governance of the IFIs: A Critical Assessment. World Bank Legal Review: International Financial Institutions and Global Legal Governance, Vol. 3 (H. Cisse, D. Bradlow, B. Kingsbury (eds)). World Bank. Available at: http://ssrn.com/abstract=1939786 (accessed 15 October 2018).

Bradlow D. (2017) Using a Shield as Sword: Are International Organizations Abusing Their Immunity? Temple International and Comparative Law Journal, vol. 31 (accessed 15 October 2018).

BRICS (2014) Treaty for the Establishment of a BRICS Contingent Reserve Arrangement. Fortaleza, 15 July. Available at: http://www.brics.utoronto.ca/docs/140715-treaty.html (accessed 15 October 2018).

Business 20 (B20) (n.d.) Official Website. Available at: https://www.b20germany.org (accessed 15 October 2018). 
Compliance Advisor Ombudsman (n.d.) Official Website. Available at: http://www.cao-ombudsman. org/about (accessed 15 October 2018).

Darrow M. (2006) Between Light and Shadow: The World Bank, The International Monetary Fund and International Human Rights Law. Oxford: Hart Publishing.

De Vries M. (1986) The IMF in a Changing World, 1945-85. Washington DC: IMF.

European Commission of Human Rights (1997) Application No. 26083/94, Richard Waite and Terry Kennedy Against Germany. Available at: https://www.google.com/url?sa=t\&rct=j\&q=\&esrc=s\&sourc $\mathrm{e}=$ web\&cd=2\&ved=2ahUKEwiw66SynebeAhWCoFsKHRq8BgkQFjABegQIBBAC\&url=http\%3A\% 2F\%2Fhudoc.echr.coe.int\%2Fapp\%2Fconversion\%2Fpdf\%2F\%3Flibrary\%3DECHR\%26id\%3D00145948\%26filename\%3D001-45948.pdf\&usg=AOvVaw1CUJisfXLh-3MBffO9di5a (accessed 15 October 2018).

European Court of Human Rights (1999) Case of Waite and Kennedy v. Germany, Application No. 26083/94. Available at: http://hudoc.echr.coe.int/eng?i=001-58912 (accessed 15 October 2018).

Federal Government of Germany (n.d.) G7 Summit: From Rambouillet to Brussels: The History of the G7. Available at: https://www.g7germany.de/Content/EN/StatischeSeiten/G7_elmau_en/texte_ en/2014-11-05-geschichte-g8.html (accessed 15 October 2018).

Financial Stability Board (FSB) (n.d.) Our History. Available at: http://www.fsb.org/about/history/ (accessed 15 October 2018).

Financial Times (2018) EU, Russia and China Agree Special Payments System for Iran. 25 September. Available at: https://www.ft.com/content/4aa03678-c0a7-11e8-8d55-54197280d3f7 (accessed 15 October 2018).

G20 (2009) Leaders' Statement. Pittsburgh, 24-25 September. Available at: http://www.g20.utoronto. ca/2009/2009communique0925.html (last visited 3 October 2018).

Global Compact Network Germany (2015) 5 Steps Towards Managing the Human Rights Impact of Your Business. Available at: https://www.globalcompact.de/wAssets/docs/Menschenrechte/Publikationen/5_steps_towards_managing_the_human_rights_impacts_of_your_business.pdf (accessed 15 October 2018).

Goodhart C. (2011) The Basel Committee on Banking Supervision: A History of the Early Years 1974-1997. Cambridge University Press.

Group of 24 (G24) (n.d.) Official Website. Available at: https://www.g24.org/ (accessed 15 October 2018). Group of 77 (G77) (n.d.) Official Website. Available at: http://www.g77.org/ (accessed 15 October 2018).

Hannum H. (1996) The Status of the Universal Declaration of Human Rights in National and International Law. Georgia Journal of International and Comparative Law, vol. 25, no 1.

Haq M.U., Jolly R., Streeten P., Haq K. (1995) The UN and the Bretton Woods Institutions: New Challenges for the 21 Century. New York: St. Martin's Press.

Helleiner E. (2014) Forgotten Foundations of Bretton Woods: International Development and the Making of the Postwar Order. Cornell University Press.

Horsefield J.K. (1969) The International Monetary Fund 1945-1965: Twenty Years of International Monetary Cooperation, Vol. 1: Chronicle. Washington DC: IMF. Available at:

http://documents.worldbank.org/curated/en/532521468149674407/pdf/833920BR0IBRD20ox0382087 B00PUBLIC0.pdf (accessed 15 October 2018).

World Bank (IBRD) (2012) IBRD Articles of Agreement: Article V. Available at: http://web.worldbank. org/WBSITE/EXTERNAL/EXTABOUTUS/0,,contentMDK:20049604 pagePK:51123644 piPK:329 829 theSitePK:29708 isCURL:Y,00.html (accessed 15 October 2018).

Human Rights Watch (2017) Letter to the World Bank on the Environmental and Social Standards Guidance Notes. 4 December. Available at: https://www.hrw.org/news/2017/12/04/letter-world-bank-environmental-and-social-standards-guidance-notes (accessed 10 October 2018) (accessed 15 October 2018). 
Hurley J., Morris S., Portelance G. (2018) Examining the Debt Implications of the Belt and Road Initiative from a Policy Perspective. Policy Paper, Center for Global Development. Available at: https:// www.cgdev.org/publication/examining-debt-implications-belt-and-road-initiative-policy-perspective (accessed 15 October 2018).

Independent Evaluation Office (IEO) (2018) Governance of the IMF: Evaluation Update. Available at: http://www.ieo-imf.org/ieo/files/updates/1802671_IEO_GOV_EVAL_UPDATE.PDF(accessed 15October 2018).

Independent Evaluation Office (IEO) (n.d.) Official Website. Available at: http://www.ieo-imf.org/ (accessed 15 October 2018).

International Monetary Fund (IMF) (1944) Articles of Agreement of the International Monetary Fund. Available at: https://www.imf.org/external/pubs/ft/aa/pdf/aa.pdf (accessed 15 October 2018).

International Monetary Fund (IMF) (2006) Article IV of The Fund's Articles of Agreement: An Overview of the Legal Framework. Washington DC, IMF. Available at: https://www.imf.org/external/np/pp/ eng/2006/062806.pdf (accessed 15 October 2018).

International Monetary Fund (IMF) (2009a) Quotas - Updated Calculations and Quota Variables, Statistical Appendix, and The Acting Chair's Summing Up of the Board Meeting August 27, 2009. Available at: https://www.imf.org/external/np/pp/eng/2009/082709.pdf (accessed 15 October 2018).

International Monetary Fund (IMF) (2009b) IMF's Public Information Notice 09/98: IMF Executive Board Discusses Governance Reform. Available at: https://www.imf.org/en/News/Articles/2015/09/28/04/53/pn0998 (accessed 15 October 2018).

International Monetary Fund (IMF) (2017a) Selected Decisions and Selected Documents of the International Monetary Fund. 39th Issue. Washington DC: IMF. Available at: https://www.imf.org/external/SelectedDecisions/Description.aspx?decision=DN5 (accessed 15 October 2018).

International Monetary Fund (IMF) (2017b) Collaboration Between Regional Financing Agreements and the IMF. IMF Policy Paper, July. Available at: https://www.imf.org/ /media/Files/Publications/ $\mathrm{PP} / 2017 / \mathrm{pp} 073117$-collaboration-between-regional-financing-arrangements-and-the-imf.ashx (accessed 15 October 2018).

International Monetary Fund (IMF) (2018) Transparency at the IMF. Available at: https://www.imf.org/ en/About/Factsheets/Sheets/2016/07/27/15/35/Transparency-at-the-IMF (accessed 15 October 2018).

International Monetary Fund (IMF) (n.d.a) IMF Executive Directors and Voting Power. Available at: https://www.imf.org/external/np/sec/memdir/eds.aspx (accessed 15 October 2018).

International Monetary Fund (IMF) (n.d.b) Financial Sector Assessment Program (FSAP). Available at: https://www.imf.org/external/np/fsap/fssa.aspx (accessed 15 October 2018).

Jessop B. (1998) The Rise of Governance and the Risks of Failure: The Case of Economic Development. International Social Science Journal, vol. 50, no 155 (accessed 15 October 2018).

Kirton J (1999) What is the G20? G20 Information Centre, Monk School of Global Affairs \& Public Policy. Available at: http://www.g20.utoronto.ca/g20whatisit.html (accessed 15 October 2018).

Labour 20 (L20) (n.d.) Official Website. Available at: http://www.120argentina.org/?s=L20\&lang=eng (accessed 15 October 2018).

Lukov V. (2012) A Global Forum for the New Generation: The Role of the BRICS and the Prospects for the Future. Available at: http://www.brics.utoronto.ca/analysis/Lukov-Global-Forum.html (accessed 15 October 2018).

Martens K., Jakobi A. (eds) (2010) Mechanisms of OECD Governance: International Incentives for National Policy-Making? Oxford University Press.

New Development Bank (NDB) (n.d.) Official Website. Available at: https://www.ndb.int/ (accessed 15 October 2018).

O’Brien R., Goetz A.M., Scholte J.A., Williams M. (2000) Contesting Global Governance: Multilateral Economic Institutions and Global Social Movements. Cambridge University Press. 
Organisation for Economic Co-operation and Development (OECD) (n.d.) History. Available at: http:// www.oecd.org/about/history/ (accessed 15 October 2016).

Stuenkel O. (2015) The BRICS and The Future of Global Order. Lexington Books.

Sussangkam C. (2010) The Chiang Mai Initiative Multilateralization: Origin, Development and Outlook. ADBI Working Paper Series no 230, ADBI Institute. Available at: https://www.adb.org/sites/default/ files/publication/156085/adbi-wp230.pdf (accessed 15 October 2018).

Think Tank 20 (T20) (n.d.) Official Website. Available at: https://t20argentina.org/publicacion/the-t20communique/ (accessed 15 October 2018).

United Nations (UN) (1944) International Monetary Fund and International Bank for Reconstruction and Development, Articles of Agreement. United Nations Monetary and Financial Conference. Available at: https://fraser.stlouisfed.org/files/docs/historical/martin/17_07_19440701.pdf (accessed 19 November 2018).

United Nations (UN) (1945) Charter of the United Nations. Available at: http://www.un.org/en/charterunited-nations/ (accessed 15 October 2018).

United Nations (UN) (1946) Convention on the Privileges and Immunities of the United Nations. Available at: http://www.un.org/en/ethics/pdf/convention.pdf (accessed 15 October 2018).

United Nations (UN) (1948a) Final Act and Related Documents. United Nations Conference on Trade and Employment. Havana, 21 November 1947-24 March 1948. Available at: https://www.wto.org/english/docs_e/legal_e/havana_e.pdf (accessed 15 October 2018).

United Nations (UN) (1948b) Universal Declaration of Human Rights. UN General Assembly Resolution 217 A (III). Available at: http://www.refworld.org/docid/3ae6b3712c.html (accessed 15 October 2018).

United Nations (UN) (n.d.) International Monetary Fund. United Nations Global Marketplace. Available at: https://www.ungm.org/Shared/KnowledgeCenter/Pages/IMF (accessed 15 October 2018).

United States Court of Appeals (2017) Jam v. International Finance Corp., No. 16-7051. DC Circuit.

Vreeland J. (2003) The IMF and Economic Development. Cambridge University Press.

Women 20 (W20) (n.d.) Official Website. Available at: http://w20argentina.com/en/ (accessed 15 October 2018).

World Bank (IBRD) (1944) Articles of Agreement. Available at: http://siteresources.worldbank.org/EXTARCHIVES/Resources/IBRD_Articles_of_Agreement.pdf (accessed 15 October 2018).

World Bank (IBRD) (1947) Agreement Between the United Nations and the Bank. Resolution 24, 16 September 1947. Available at: http://documents.worldbank.org/curated/en/532521468149674407/pdf /833920BR0IBRD20ox0382087B00PUBLIC0.pdf (accessed 15 October 2018).

World Bank (IBRD) (2015) Bank Policy: Access to Information. Available at: http://pubdocs.worldbank. org/en/393051435850102801/World-Bank-Policy-on-Access-to-Information-V2.pdf (accessed 15 October 2018).

World Bank (IBRD) (2016) The New Environmental and Social Framework. Available at: http://www. worldbank.org/en/news/feature/2016/08/05/the-new-environmental-and-social-framework (accessed 15 October 2018).

World Bank (IBRD) (n.d.a) About World Bank. Available at: https://www.worldbank.org/en/what-wedo (accessed 15 October 2018).

World Bank (IBRD) (n.d.b) Board of Executive Directors Updates. Available at: http://www.worldbank. org/en/about/leadership/directors (accessed 15 October 2018).

World Bank (IBRD) (n.d.c) Financial Sector Assessment Program (FSAP). Available at: http://www. worldbank.org/en/programs/financial-sector-assessment-program (accessed 15 October 2018).

World Bank (IBRD) (n.d.d) What We Do. Available at: http://www.worldbank.org/en/what-we-do (accessed 15 October 2018). 
World Bank (IBRD) (n.d.e) Board Facts. Available at: http://web.worldbank.org/WBSITE/EXTERNAL/EXTABOUTUS/ORGANIZATION/BODEXT/0,,contentMDK:50004880 menuPK:6673256 pagePK:64020054 piPK:64020408 theSitePK:278036,00.html (accessed 15 October 2018).

World Bank (IBRD) (n.d.f) About the Inspection Panel. Available at: http://www.inspectionpanel.org/ about-us/about-inspection-panel (accessed 15 October 2018).

World Trade Organization (WTO) (n.d.) The General Agreement on Tariffs and Trade (GATT 1947). Available at: https://www.wto.org/english/docs_e/legal_e/gatt47_01_e.htm (accessed 15 October 2018). 


\title{
Оценка потенциала реформ системы глобального экономического управления ${ }^{1}$
}

\author{
Д.Д. Брэдлоу
}

Брэдлоу Дэниел Д. - профессор в сфере международного законодательства в области развития и экономических отношений в Африке, Центр по правам человека, юридический факультет Университета Претории; University of Pretoria, Private bag X20, Hatfield 0028, South Africa; E-mail: danny.bradlow@up.ac.za

Любая динамичная социальная система обладает ограниченным потенциалом для адаптации. Способность правовой и институциональной структуры какой-либо системы приспосабливаться к меняющимся условиям деятельности не безгранична. Следовательно, если система не подвергается существенной перестройке, она начинает терять свою легитимность и эффективность.

Автор статьи утверждает, ито структура, модель функционирования и масштаб мировой экономики изменились настолько существенно, что современная модель глобального экономического управления приблизилась $\kappa$ пределу своей эффективности. Действующие механизмы уже неспособны обеспечить инклюзивность, устойчивость и эффективность международной экономической системы, которая могла бы поддерживать международный мир и процветание, а также производить социальные блага. Данные механизмы, управленческие практики и процедуры не были в полной мере адаптированы к новым реалиям мировой экономики. Ключевые международные экономические институты медленно приспосабливаются к изменившемуся соотношению сил среди их членов. Они с опозданием реагируют на растущую роль корпораций, институтов гражданского общества и наднациональных органов в глобальном экономическом управлении.

Как бы то ни было, наблюдается недостаток политической воли, необходимой для реформирования институциональной структуры глобального экономического управления. Из этого следует, что без серьезного кризиса потенциал для реформ представляется ограниченным в кратко- и среднесрочной перспективе. Однако это не означает, что не существует возможности для проведения продуманных узконаправленных реформ. Акторы, заинтересованные в осуществлении реформ, должны тщательно работать над выявлением подобных возможностей, а обнаружив их, - использовать шанс для того, чтобы сделать систему более открытой к участию, подотчетной и динамичной в интересах проведения более существенных реформ глобального экономического управления в будущем.

Данная статья вначале обращается к ключевым особенностям миропорядка, созданного после Второй мировой войны. Следом рассматриваются некоторые изменения, которым подверглись созданные институты в течение последних 70 лет. Наряду с этим в статье рассматриваются изменения в самой системе глобального экономического управления, а также возможные пути для выявления возможностей сделать систему более инклюзивной, динамичной и подотчетной. В заключительном разделе приводятся некоторые предположения относительно того, какие изменения возможны в текущих условиях и какую роль в претворении данных изменений в жизнь могут сыграть такие институты, как «руппа двадиати» и БРИКС.

В силу ограниченности объема данной статьи мы, рассматривая систему глобального экономического управления в целом, в основном фокусируемся на примерах двух наиболее важных институтов данной системы Международном валютном фонде (МВФ) и Группе Всемирного банка (Всемирный банк). Причина, по которой МВФ необходимо уделить внимание, состоит в том, что в настоящий момент он является наиболее значимым среди действующих многосторонних институтов в сфере международных финансов и монетарной политики. Всемирный банк играет важнейшую роль в содействии международному развитию, даже если он не является крупнейшим кредитором. Всемирный банк стал моделью для формирования всех региональных многосторонних банков развития (МБР), а также оказал влияние на структуру и функционал остальных МБР, таких как Азиатский банк инфраструктурных инвестиций (АБИИ). Кроме того, Всемирный банк всегда играл весомую роль в финансировании международного развития.

${ }^{1}$ Статья поступила в редакцию в октябре 2018 г.

Перевод выполнен А.А. Игнатовым, м.н.с. Центра исследований международных институтов Российской академии народного хозяйства и государственной службы при Президенте РФ. 
Ключевые слова: глобальное управление; Международный валютный фонд; Всемирный банк

Для цитирования: Брэдлоу Д.Д. (2018) Оценка потенциала реформ системы глобального экономического управления // Вестник международных организаций. Т. 13. № 4. С. 213-236 (на русском и английском языкаx). DOI: 10.17323/1996-7845-2018-04-10

\section{Источники}

Aizawa M., Bradlow D., Wachenfeld M. (2018) International Financial Regulatory Standards and Human Rights: Connecting the Dots // Manchester Journal of International Economic Law. T.15. № 1. Режим доступа: https://papers.ssrn.com/sol3/papers.cfm?abstract_id=3171933 (дата обращения: 15.10.2018).

Asia-Pacific Economic Cooperation (APEC) (n.d.) How APEC Operates. Режим доступа: https://www.apec. org/About-Us/How-APEC-Operates (дата обращения: 15.10.2018).

Bank for International Settlements (BIS) (n.d.a) BIS History - Overview. Режим доступа: https://www.bis. org/about/history_newarrow.htm (дата обращения: 15.10.2018).

Bank for International Settlements (BIS) (n.d.b) G10. Режим доступа: https://www.bis.org/list/g10publications/ (дата обращения: 15.10.2018).

Bradlow D. (1996) The World Bank, the IMF and Human Rights: Symposium: Social Justice and Development: Critical Issues Facing the Bretton Woods System // Transnational Law and Contemporary Problems. T.6.

Bradlow D. (2011) The Reform of the Governance of the IFIs: A Critical Assessment. World Bank Legal Review: International Financial Institutions and Global Legal Governance (H. Cisse, D. Bradlow, B. Kingsbury (eds)). World Bank. Режим доступа: http://ssrn.com/abstract=1939786 (дата обращения: 15.10.2018).

Bradlow D. (2017) Using a Shield as Sword: Are International Organizations Abusing Their Immunity? // Temple International and Comparative Law Journal. T. 31.

BRICS (2014) Treaty for the Establishment of a BRICS Contingent Reserve Arrangement, July 15, Fortaleza, Brazil. Режим доступа: http://www.brics.utoronto.ca/docs/140715-treaty.html (дата обращения: 15.10.2018).

Business 20 (B20) (n.d.) Official Website. Режим доступа: https://www.b20germany.org/ (дата обращения: 15.10.2018).

Compliance Advisor Ombudsman (n.d.) Official Website. Режим доступа: http://www.cao-ombudsman.org/ about/ (дата обращения: 15.10.2018).

Darrow M. (2006) Between Light and Shadow: The World Bank, The International Monetary Fund and International Human Rights Law. Oxford: Hart Publishing.

De Vries M. (1986) The IMF in a Changing World, 1945-85. Washington DC: IMF.

European Commission of Human Rights (1997) Application No. 26083/94, Richard Waite and Terry Kennedy Against Germany. Режим доступа: https://www.google.com/url?sa=t\&rct=j\&q=\&esrc=s\&sourc $\mathrm{e}=$ web\&cd=2\&ved=2ahUKEwiw66SynebeAhWCoFsKHRq8BgkQFjABegQIBBAC\&url=http\%3A\% 2F\%2Fhudoc.echr.coe.int\%2Fapp\%2Fconversion\%2Fpdf\%2F\%3Flibrary\%3DECHR\%26id\%3D00145948\%26filename\%3D001-45948.pdf\&usg=AOvVaw1CUJisfXLh-3MBffO9di5a （дата обращения: 15.10.2018).

European Court of Human Rights (1999) Case of Waite and Kennedy v. Germany, Application No. 26083/94. Режим доступа: http://hudoc.echr.coe.int/eng?i=001-58912 (дата обращения: 15.10.2018).

Federal Government of Germany (n.d.) G7 Summit: From Rambouillet to Brussels: The History of the G7. Режим доступа: https://www.g7germany.de/Content/EN/StatischeSeiten/G7_elmau_en/texte_en/201411-05-geschichte-g8.html (дата обращения: 15.10.2018).

Financial Stability Board (FSB) (n.d.) Our History. Режим доступа: http://www.fsb.org/about/history/ (дата обращения: 15.10.2018).

Financial Times (2018) EU, Russia and China Agree Special Payments System for Iran. 25 September. Peжим доступа: https://www.ft.com/content/4aa03678-c0a7-11e8-8d55-54197280d3f7 (дата обращения: 15.10.2018) 
G20 (2009) Leaders' Statement. Pittsburgh, 24-25 September. Режим доступа: http://www.g20.utoronto. ca/2009/2009communique0925.html (дата обращения: 15.10.2018).

Global Compact Network Germany (2015) 5 Steps Towards Managing the Human Rights Impact of Your Business. Режим доступа: https://www.globalcompact.de/wAssets/docs/Menschenrechte/Publikationen/5_ steps_towards_managing_the_human_rights_impacts_of_your_business.pdf (дата обращения: 15.10.2018).

Goodhart C. (2011) The Basel Committee on Banking Supervision: A History of the Early Years 1974-1997. Cambridge University Press.

Group of 24 (G24) (n.d.) Official Website. Режим доступа: https://www.g24.org/ (дата обращения: 15.10.2018).

Group of 77 (G77) (n.d.) Official Website. Режим доступа: http://www.g77.org/ (дата обращения: 15.10.2018).

Hannum H. (1996) The Status of the Universal Declaration of Human Rights in National and International Law // Georgia Journal of International and Comparative Law. T. 25. № 1.

Haq M.U., Jolly R., Streeten P., Haq K. (1995) The UN and the Bretton Woods Institutions: New Challenges for the 21 Century. New York: St. Martin's Press.

Helleiner E. (2014) Forgotten Foundations of Bretton Woods: International Development and the Making of the Postwar Order. Cornell University Press.

Horsefield J.K. (1969) The International Monetary Fund 1945-1965: Twenty Years of International Monetary Cooperation, Vol. 1: Chronicle. Washington DC: IMF. Режим доступа:

http://documents.worldbank.org/curated/en/532521468149674407/pdf/833920BR0IBRD20ox0382087B00P UBLIC0.pdf (дата обращения: 15.10.2018).

Human Rights Watch (2017) Letter to the World Bank on the Environmental and Social Standards Guidance Notes. 4 December. Режим доступа https://www.hrw.org/news/2017/12/04/letter-world-bank-environmental-and-social-standards-guidance-notes (дата обращения: 15.10.2018).

Hurley J., Morris S., Portelance G. (2018) Examining the Debt Implications of the Belt and Road Initiative from a Policy Perspective. Policy Paper, Center for Global Development. Режим доступа: https://www.cgdev. org/publication/examining-debt-implications-belt-and-road-initiative-policy-perspective (дата обращения: 15.10.2018).

Independent Evaluation Office (IEO) (2018) Governance of the IMF: Evaluation Update. Режим доступа: http://www.ieo-imf.org/ieo/files/updates/1802671_IEO_GOV_EVAL_UPDATE.PDF (дата обращения: 15.10.2018).

Independent Evaluation Office (IEO) (n.d.) Official Website. Режим доступа: http://www.ieo-imf.org/ (дата обращения: 15.10.2018).

International Monetary Fund (IMF) (1945) Articles of Agreement of the International Monetary Fund. Peжим доступа: https://www.imf.org/external/pubs/ft/aa/pdf/aa.pdf (дата обращения: 15.10.2018).

International Monetary Fund (IMF) (1947) Selected Decisions and Selected Documents of the International Monetary Fund. 39th Issue. Washington DC: IMF. Режим доступа: https://www.imf.org/external/SelectedDecisions/Description.aspx?decision=DN5 (дата обращения: 15.10.2018).

International Monetary Fund (1996) IMF History (1945-1965). Режим доступа: https://www.elibrary.imf. org/view/IMF071/14523-9781451955255/14523-9781451955255/front.xml (дата обращения: 20.10.2018).

International Monetary Fund (IMF) (2006) Article IV of The Fund's Articles of Agreement: An Overview of the Legal Framework. Washington DC, IMF. Режим доступа: https://www.imf.org/external/np/pp/ eng/2006/062806.pdf (дата обращения: 15.10.2018).

International Monetary Fund (IMF) (2009a) Quotas - Updated Calculations and Quota Variables, Statistical Appendix, and The Acting Chair's Summing Up of the Board Meeting August 27, 2009. Режим доступа: https://www.imf.org/external/np/pp/eng/2009/082709.pdf (дата обращения: 15.10.2018).

International Monetary Fund (IMF) (2009b) IMF's Public Information Notice 09/98: IMF Executive Board Discusses Governance Reform. Режим доступа: https:/www.imf.org/en/News/Articles/2015/09/28/04/53/ pn0998 (дата обращения: 15.10.2018). 
International Monetary Fund (IMF) (2017) Collaboration Between Regional Financing Agreements and the IMF. IMF Policy Paper, July. Режим доступа: https://www.imf.org/ /media/Files/Publications/PP/2017/ pp073117-collaboration-between-regional-financing-arrangements-and-the-imf.ashx (дата обращения: 15.10.2018).

International Monetary Fund (IMF) (2010) Transparency at the IMF. Режим доступа: https://www.imf.org/ en/About/Factsheets/Sheets/2016/07/27/15/35/Transparency-at-the-IMF (дата обращения: 15.10.2018).

International Monetary Fund (IMF) (n.d.a) IMF Executive Directors and Voting Power. Режим доступа: https://www.imf.org/external/np/sec/memdir/eds.aspx (дата обращения: 15.10.2018).

International Monetary Fund (IMF) (n.d.b) Financial Sector Assessment Program (FSAP). Режим доступа: https://www.imf.org/external/np/fsap/fssa.aspx (дата обращения: 15.10.2018).

Jessop B. (1998) The Rise of Governance and the Risks of Failure: The Case of Economic Development // International Social Science Journal. T. 50. № 155.

Kirton, J (1999) What is the G20? G20 Information Centre, Monk School of Global Affairs \& Public Policy. Режим доступа: http://www.g20.utoronto.ca/g20whatisit.html (дата обращения: 15.10.2018).

Labour 20 (L20) (n.d.) Official Website. Режим доступа: http://www.120argentina.org/?s=L20\&lang=eng (дата обращения: 15.10.2018).

Lukov V. (2012) A Global Forum for the New Generation: The Role of the BRICS and the Prospects for the Future. Режим доступа: http://www.brics.utoronto.ca/analysis/Lukov-Global-Forum.html (дата обращения: 15.10.2018).

Martens K., Jakobi A. (eds) (2010) Mechanisms of OECD Governance: International Incentives for National Policy-Making? Oxford University Press.

New Development Bank (NDB) (n.d.) Official Website. Режим доступа: https://www.ndb.int/ (дата обращения: 15.10.2018).

O'Brien R., Goetz A.M., Scholte J.A., Williams M. (2000) Contesting Global Governance: Multilateral Economic Institutions and Global Social Movements. Cambridge University Press.

Organisation for Economic Co-operation and Development (OECD) (n.d.) History. Режим доступа: http:// www.oecd.org/about/history/ (дата обращения: 15.10.2018).

Stuenkel O. (2015) The BRICS and The Future of Global Order. Lexington Books.

Sussangkam C. (2010) The Chiang Mai Initiative Multilateralization: Origin, Development and Outlook. ADBI Working Paper Series no 230, ADBI Institute. Режим доступа: https://www.adb.org/sites/default/ files/publication/156085/adbi-wp230.pdf (дата обращения: 15.10.2018).

Think Tank 20 (T20) (n.d.) Official Website. Режим доступа: https://t20argentina.org/publicacion/the-t20communique/ (дата обращения: 15.10.2018).

United Nations (UN) (1944) International Monetary Fund and International Bank for Reconstruction and Development, Articles of Agreement. United Nations Monetary and Financial Conference. Режим доступа: https://fraser.stlouisfed.org/files/docs/historical/martin/17_07_19440701.pdf (дата обращения: 19.11.2018).

United Nations (UN) (1945) Charter of the United Nations. Режим доступа: http://www.un.org/en/charterunited-nations/ (дата обращения: 15.10.2018).

United Nations (UN) (1946) Convention on the Privileges and Immunities of the United Nations. Режим доступа: http://www.un.org/en/ethics/pdf/convention.pdf (дата обращения: 15.10.2018).

United Nations (UN) (1948a) Final Act and Related Documents. United Nations Conference on Trade and Employment. Havana, 21 November 1947-24 March 1948. Режим доступа: https://www.wto.org/english/ docs_e/legal_e/havana_e.pdf (дата обращения: 15.10.2018).

United Nations (UN) (1948b) Universal Declaration of Human Rights. UN General Assembly Resolution 217 A (III). Режим доступа: http://www.refworld.org/docid/3ae6b3712c.html (дата обращения: 15.10.2018).

United Nations (UN) (n.d.) International Monetary Fund. United Nations Global Marketplace. Режим доступа: https://www.ungm.org/Shared/KnowledgeCenter/Pages/IMF (дата обращения: 15.10.2018).

United States Court of Appeals (2017) Jam v. International Finance Corp., No. 16-7051. DC Circuit.

Vreeland J. (2003) The IMF and Economic Development. Cambridge University Press. 
Women 20 (W20) (n.d.) Official Website. Режим доступа: http://w20argentina.com/en/ (дата обращения: 15.10.2018).

World Bank (IBRD) (1945) Articles of Agreement. Режим доступа: http://siteresources.worldbank.org/EXTARCHIVES/Resources/IBRD_Articles_of_Agreement.pdf (дата обращения: 15.10.2018).

World Bank (IBRD) (1947) Agreement Between the United Nations and the Bank. Resolution 24, 16 September 1947. Режим доступа: http://documents.worldbank.org/curated/en/532521468149674407/pdf/833920BR 0IBRD20ox0382087B00PUBLIC0.pdf (дата обращения: 15.10.2018).

World Bank (IBRD) (2010) The World Bank Policy on Access to Information. Режим доступа: http://www. worldbank.org/en/access-to-information (дата обращения: 15.10.2018).

World Bank (IBRD) (2012) IBRD Articles of Agreement: Article V. Режим доступа: http://web.worldbank. org/WBSITE/EXTERNAL/EXTABOUTUS/0,,contentMDK:20049604 pagePK:51123644 piPK:329829 t heSitePK:29708 isCURL:Y,00.html (дата обращения: 15.10.2018).

World Bank (IBRD) (2016) The New Environmental and Social Framework. Режим доступа: http://www. worldbank.org/en/news/feature/2016/08/05/the-new-environmental-and-social-framework (дата обращения: 15.10.2018).

World Bank (IBRD) (n.d.a) About World Bank. Режим доступа: https://www.worldbank.org/en/what-we-do (дата обращения: 15.10.2018).

World Bank (IBRD) (n.d.b) Board of Executive Directors Updates. Available at: http://www.worldbank.org/ en/about/leadership/directors (дата обращения: 15.10.2018).

World Bank (IBRD) (n.d.c) Financial Sector Assessment Program (FSAP). Режим доступа: http://www. worldbank.org/en/programs/financial-sector-assessment-program (дата обращения: 15.10.2018).

World Bank (IBRD) (n.d.d) What We Do. Режим доступа: http://www.worldbank.org/en/what-we-do (дата обращения: 15.10.2018).

World Bank (IBRD) (n.d.e) Board Facts. Режим доступа: http://web.worldbank.org/WBSITE/EXTERNAL/EXTABOUTUS/ORGANIZATION/BODEXT/0,,contentMDK:50004880 menuPK:6673256 pageP K:64020054 piPK:64020408 theSitePK:278036,00.html (дата обрашения: 15.10.2018).

World Bank (IBRD) (n.d.f) About the Inspection Panel. Режим доступа: http://www.inspectionpanel.org/ about-us/about-inspection-panel (дата обращения: 15.10.2018).

World Bank (IBRD) (2010) Bank Policy: Access to Information. Режим доступа: http://pubdocs.worldbank. org/en/393051435850102801/World-Bank-Policy-on-Access-to-Information-V2.pdf (дата обращения: 15.10.2018).

World Trade Organization (WTO) (1947) The General Agreement on Tariffs and Trade (GATT 1947). Available at: https://www.wto.org/english/docs_e/legal_e/gatt47_01_e.htm (дата обращения: 15.10.2018). 